\title{
INCIDENCE OF TRAUMATIC PARAPLEGIA AND TETRAPLEGIA IN NORWAY: A STATISTICAL SURVEY OF THE YEARS 1974 AND 1975
}

By Ragnar Gjone, M.D. and Lasse Nordlie, M.D.

Sunnaas Hospital, Nesodden, Norway

Abstract. A survey based on interviews with all Norwegian hospitals, 62 in number, showed that in 1974 and 1975 respectively 65 and 66 traumatic spinal cord and cauda equina lesions were treated in Norway, a total of I3I or 16.5/million inhabitants/year.

Key words: Spinal injuries; Incidence.

\section{Introduction}

TO DATE the only reliable data available on a national scale on the incidence of traumatic spinal lesions have been published by Gehrig and Michaelis in 1968, relating to Switzerland during the years 1960 to 1967 . This survey concluded with an average incidence of 13.4 new cases per million inhabitants per year and an increase from I I to I 5 new injuries/million inhabitants/year during the period of registration. Based on these figures it would now seem realistic to assume an incidence of 15 to 20 new cases/million inhabitants/year in the western industrial countries. A recent monography published by Kurtzke (1975) on the 'Epidemiology of spinal cord injury' claims that an incidence of 30 is a more realistic assumption, based on statistical material from a number of Spinal Units throughout the world. He emphasises that this figure includes only surviving patients.

Both in order to improve our existing Spinal Injuries Service and to secure a better background for long-term planning on a larger scale, it seemed important to establish more up-to-date and exact figures than those referred to here. As in the case of Switzerland, Norway is a small country with a highly organised Health Service, well suited to a survey on a national scale.

\section{Material and Methods}

Our aim has been a reliable survey of the number of spinal injuries during the years 1974 and 1975. In January 1976 we wrote to all 62 Norwegian hospitals, requesting information regarding all lesions with traumatic paraplegia and tetraplegia they had treated during the 2 years in question. In order to secure the best possible response we made our questionnaire fairly simple. We did, however, include the level of injury, referring both to the bony injury and the cord lesion, and specifying conus and cauda equina lesions, as well as the question of complete or incomplete lesions. We also asked to be registered sex, date of birth and date of injury. This was a safeguard against duplicate registration, since no patient was registered by name. (A condition stipulated by the Ministry of Health.) After 9 months-and several reminders-all hospitals had returned the questionnaire. Of the 62 hospitals 25 had admitted no cases of traumatic spinal lesions during the 2 years in question. With one exception, all remaining 37 hospitals 
returned the questionnaire correctly filled in. Our survey was met with great interest and goodwill, and no fewer than 18 hospitals sent us additional information connected with the patients.

\section{Results}

We had made it quite clear that the data we needed referred to patients treated, i.e. to surviving patients with spinal cord or cauda equina lesions. However, some questionnaires were returned with information on patients 'dead on admission' as well as cases of cord concussion and cervical injuries with root lesions only.

Eliminating these three categories we were left with 65 spinal cord and cauda equina lesions for 1974 and 66 for I975, a total of I3I cases, or I6.5 per million inhabitants per year (Table I) (83 per cent male, I 7 per cent female).

The age average was 37 years (Table II). The age distribution was as expected: 52 per cent in the age group 15 to 40 . We note that less than 5 per cent (six patients) were under I 5 , while as many as 20 per cent were over 60 . country.

It is interesting to note (Table III) the even distribution throughout the

Table IV shows the proportion of high and low lesions, indicating the slightly higher number of tetraplegics.

\section{TABLE I}

Traumatic spinal cord injuries in Norway $1974-75$

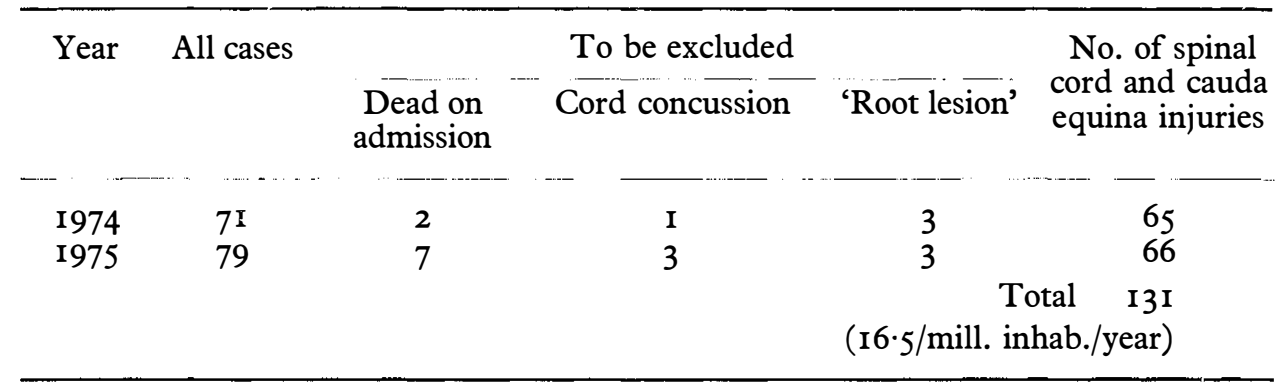

TABLE II

Traumatic spinal cord injuries in Norway $1974-75$

\begin{tabular}{cc}
\hline Age & No. of patients \\
\hline $0-20$ & $23(17 \%)$ \\
$20-40$ & $51(39 \%)$ \\
$40-60$ & $31(24 \%)$ \\
$60-$ & $26(20 \%)$ \\
Total & I3I
\end{tabular}

Mean age: $37 \quad$ Female: $22(17 \%)$

I 5-40 years: $68(52 \%)$ Male: Io9 $(83 \%)$ 
TABLE III

Traumatic spinal cord injuries in Norway 1974-75. Geographical distribution

\begin{tabular}{lcr}
\hline \multicolumn{1}{c}{ District } & $\%$ of population & $\%$ of injuries \\
\hline Eastern Norway & 55 & $56(\mathrm{~N}: 74)$ \\
Western Norway & 24.5 & $23(\mathrm{~N}: 30)$ \\
Mid- and North Norway & 20.5 & $21(\mathrm{~N}: 27)$ \\
$\quad$ Total & & $\mathrm{N}:$ I3 I \\
\hline
\end{tabular}

\section{TABLE IV}

Traumatic spinal cord injuries in Norway I974-75

$\left.\begin{array}{ll}\hline \multicolumn{1}{c}{\text { Level of lesion }} & \text { No. of patients } \\ \hline \text { Cervical } & 69(53 \%) \\ \text { Dorsal } & 34 \\ \text { Lumbar } & \text { 16 } \\ \text { Conus/cauda equina } & \text { 12 }\end{array}\right\} 62(47 \%)$

This seems rather unexpected but the figures in Table $\mathrm{V}$ may give the reason. This table shows complete and incomplete lesions in relation to the level of injury. Within the thoracic injuries ( 55 per cent of the paraplegics) we find, not unexpectedly, that the complete lesions dominate, while the opposite is the case of the cervical injuries. The fact that as many as 62 per cent of the cervical lesions are registered as incomplete gives rise to the assumption that a number of these may be whiplash injuries, without cord lesion.

Table VI is a further illustration of this assumption. The total of I4 (of 43) incomplete cervical lesions without bony injury would indicate that our patient material includes several very slight injuries, especially since ten of these derive from two hospitals. Furthermore 23, or slightly more than half the total number of incomplete lesions, originated from the same two hospitals.

We felt justified in concluding that the present registration has not resulted

\section{TABLE V}

Traumatic spinal cord injuries in Norway 1974-75. Neurological deficit

\begin{tabular}{lrrr}
\hline Level of lesion & Complete & Incomplete & Total \\
\hline Cervical & $26(38 \%)$ & $43(62 \%)$ & 69 \\
Dorsal & $24(71 \%)$ & I0 $(29 \%)$ & 34 \\
Lumbar & $7(44 \%)$ & $9(56 \%)$ & 16 \\
Conus/cauda eq. & & 12 \\
\multicolumn{4}{c}{ Cord lesions: Complete $57(48 \%)$} \\
\multicolumn{3}{c}{ Incomplete 62 $(52 \%)$} \\
\hline
\end{tabular}


TABLE VI

Traumatic spinal cord injuries in Norway 1974-75. Cord lesions without bony injury

\begin{tabular}{lcc}
\hline Level of lesion & Complete & Incomplete \\
\hline Cervical & $2(\mathrm{~N}: 26)$ & I4 $(\mathrm{N}: 43)$ \\
Dorsal & $\mathrm{O}(\mathrm{N}: 24)$ & $4(\mathrm{~N}:$ IO) \\
Lumbar & $\mathrm{O}(\mathrm{N}: 7)$ & $2(\mathrm{~N}: 9)$
\end{tabular}

Total number of cord lesions: I I9

Without bony injury: 22 ( $18 \%$ )

in too high an estimate of the incidence of spinal lesions in Norway for the years I974 and 1975 .

\section{Comments}

Our conclusion, 16.5 spinal injuries/million inhabitants/year implies that the figures of Gehrig and Michaelis (1968) for Switzerland 1960-67 still are valid as a basis for the planning of Spinal Injuries service in the western industrial countries.

And what is the situation in Norway? To quote Sir Ludwig Guttmann (1973): 'There are no proper Spinal Injury units in any of the Scandinavian countries which can give paraplegics and tetraplegics a comprehensive treatment and rehabilitation from the start. In these countries there still exists the fragmentation of treatment and the initial and early treatment is carried out in neurosurgical and orthopaedic departments, and the patients are then transferred to General Rehabilitation Centres'. Unfortunately this cannot be denied. This fragmentation of treatment is still practised. It is a Scandinavian tradition, and up to now we have had to work according to this principle. I have no intention especially not here, of defending this principle, but I will, however, stress the fact that it at least assures the patients an optimum treatment of accompanying injuries such as thorax lesions, intra-abdominal bleeding, craniocerebral lesions. Furthermore, I would like to assert that we try to compensate for the lack of comprehensive care by (I) centralising the treatment during the rehabilitation phase, (2) initiating this phase as early as possible, preferably through (3) contact with the surgical department prior to transfer to Sunnaas Hospital. Though we have not yet reached our goal we have at least come part of the way.

At Sunnaas Hospital, our largest hospital for medical rehabilitation, situated near Oslo, we have during the past 6 years established a 25-bed Spinal Cord Department. Some 30 to 40 new cases from all over the country are now being treated every year and in addition some 30 patients return for check-up regularly.

Seventy cases, or 53.5 per cent of the total of I3I spinal injuries in Norway 1974/75 were treated at Sunnaas Hospital (Table VII). As opposed to the overall material we had more paraplegics than tetraplegics and a preponderance of complete lesions (Table VIII). A total of 40 complete lesions were treated in our Spinal Unit, i.e. 70 per cent of all cases (Table VII) registered in Norway 1974/75. In fact the present situation is that we treat the majority of the serious spinal lesions in Norway. Our capacity is, unfortunately, too small to meet the needs on a national scale, and many of our patients have to remain too long in the 
TABLE VII

Traumatic spinal cord injuries I974-75

\begin{tabular}{lcc}
\hline & $\begin{array}{c}\text { Norway: total } \\
\text { no. of patients }\end{array}$ & $\begin{array}{c}\text { Sunnaas Hospital: } \\
\text { no. of cases }\end{array}$ \\
\hline All injuries & I3 & $70(53 \cdot 5 \%)$ \\
Complete lesions & 57 & $40(70 \%)$ \\
\hline
\end{tabular}

TABLE VIII

Traumatic spinal cord injuries in Sunnaas Hospital I974-75

\begin{tabular}{lc}
\hline I974: 32 cases \\
I975: 38 cases $\}$ & 70 cases \\
\begin{tabular}{ll} 
Paraplegia $36(52 \%)$ & Tetraplegia $34(48 \%)$ \\
Complete $40(57 \%)$ & Incomplete $30(43 \%)$ \\
\hline
\end{tabular} \\
\hline
\end{tabular}

primary hospitals. The result is that the traditional fragmentation of treatment unfortunately still suffers from the traditional complications. (In a material of I 2 cases 23 per cent developed bladder stones and 25 per cent had bed sores of varying sizes.)

Our statistical survey has given us information on the incidence of traumatic spinal lesions in Norway, and we can legitimately conclude that an expansion of our spinal unit to 40-50 beds would satisfy the requirements for optimum treatment in both phases after injury. The question is: are we also in the future to accept this fragmentation of treatment. There are no serious obstacles in securing the necessary facilities for a fully equipped Spinal Unit, and, in my opinion, we have now reached the point where these questions must receive serious consideration from the Norwegian Health Authorities at the highest level.

\section{SUMMARY}

A survey based on interviews with all Norwegian hospitals, 62 in number, showed that in 1974 and 1975 respectively 65 and 66 traumatic spinal cord and cauda equina lesions were treated in Norway, a total of $13 \mathrm{I}$ or $16.5 /$ million inhabitants/year. Sixty-nine ( 53 per cent) of these patients had cervical lesions, 50 had thoraco-lumbar and 12 had conus or cauda equina lesions. Forty-eight per cent of the cord injuries were complete ( 38 per cent cervical and 62 per cent thoraco-lumbar injuries). Eighty-three per cent of the patients were male, and the average age was 37 years.

\section{RÉSUMÉ}

La participation des hôpitaux norvégiens à des interview par questionnaire montre en 1974 et 1975 respectivement 65 et 66 victimes de lésions de la moelle épinière et du cauda equina en Norvège, un total de I3I ou I6,5/mill.hab./an. On note un total de 69 $(53 \%)$ de lésions cervicales, 50 lésions thoraco-lombales et $\mathrm{I} 2$ lésions conus/cauda equina. 
Des lésions de la moelle épiniére $48 \%$ êtaient complètes $(38 \%$ cervicales, $62 \%$ thoracolombales), $83 \%$ mâles et l'âge moyenne 37 ans.

\section{ZUSAMMENFASSUNG}

Eine Übersicht auf Grund von Verfragungen in sämtlichen 62 Norwegischen Krankenhäusern hat gezeigt, dass während den Jahren I974 und I975 je 65 und 66 traumatische Verletzungen von Rückenmark und Cauda equina in Norwegen behandelt wurden, insgesamt I3 I oder I6,5/Million Einwohnern/Jahr. 69 (53\%) von den Patienten haben zervicale Verletzungen gehabt, 50 hatten thoraco-lumbale und 12 Patienten haben Conus- oder Cauda equina- Verletzungen gehabt. $48 \%$ von den Rückenmarksverletzungen waren komplette Läsionen (je $38 \%$ von den zervikalen und $62 \%$ von den thoraco-lumbalen Verletzungen). $83 \%$ von den Patienten waren Männer, und das Durchschnittsalter war 37 Jahre.

\section{REFERENCES}

Gehrig, R. \& Michaelis, L. S. (I968). Statistics of acute paraplegia and tetraplegia on a national scale: Switzerland I960-67. Paraplegia, 5, 93-95.

Guttmann, Sir L. (1973). Spinal Cord Injuries. Comprehensive Management and Research. Blackwell Scientific Publications, Oxford, p. 34.

KuRTzKe, J. F. (1975). Epidemiology of spinal cord injury. Experimental Neurology, 48, I63-236. 